УДК 343.98

DOI https://doi.org/10.32849/2663-5313/2021.2.51

\title{
Олександр Цивінсъкий,
}

стариий детектив - керівник Третього відділу

детективів Другого підрозділу детективів

Головного підрозділу детективів

Національного антикорупційного бюро України

\section{Оксана Дуфенюк,}

канд. юрид. наук, дочент,

доцент кафедри кримінального процесу та криміналістики

факультету № 1

Інституту з підготовки фахівців для підрозділів Національної поліиї

Львівського державного університету внутрішніх справ

\section{ПРОБЛЕМНІ ПИТАННЯ СУДОВО-ЕКОНОМІЧНОЇ ЕКСПЕРТИЗИ У КРИМІНАЛЬНОМУ ПРОВАДЖЕННІ}

Стаття присвячена обговоренню складної практичної проблеми використання спеціальних економічних знань у кримінальному провадженні, що є обов'язковим елементом протидї «білокоміриевій злочинності». Метою дослідження є визначення суперечностей між чинними нормами права та чинною судово-слідчою практикою залучення судових експертів-економістів для проведення експертиз.

Доведено, що нормативно-правове забезпечення для кожного виду судових експертиз має вагоме значення. Часто основними документами судово-економічної експертизи, на підставі яких робляться висновки про фінансово-господарські операції, $є$ документи позапланових ревізій і перевірок уповноважених суб'єктів фінансового контролю. 3 урахуванням змін законодавства 32015 р. перестала діяти норма, яка передбачала можливість проведення таких позапланових перевірок і ревізій з інічіативи органу досудового розслідування.

Упродовж тривалого часу слідчі зверталися до слідчого судді для отримання дозволу на проведення ревізій і перевірок, однак ия практика припинена у 2018 р. Верховним Судом Украйни, який у рішеннях висловив правову позицію, що в слідчого судді таких повноважень немає. Відтак апелячійні суди почали скасовували такі ухвали.

Другий шлях, який обрали органи досудового розслідування, полягав у залученні прачівників органів фінансового контролю або експертних підрозділів спочатку як спечіалістів і в подальшому скеруванні для проведення економічних експертиз складених у результаті таких дій довідок. Ця практика також припинена Верховним Судом України через невідповідність об'єкта дослідження. На думку Феміди, довідка спеціаліста не тотожна акту позапланової ревізії чи перевірки. Тож, застосовуючи доктрину «плодів отруєного дерева», суди почали визнавати висновки судово-економічних експертиз, які підготовлені з використанням довідок спечіалістів, недопустимими джерелами доказів.

Як наслідок, органи досудового розслідування в результаті таких непродуманих змін у законодавстві втратили можливість ініціювання та проведення позапланових ревізій і перевірок, що суттєво ускладнило залучення судових економічних експертів для з'ясування обставин, які входять до предмета доказування й щодо яких існує пряма вимога законодавия проводити експертизи. Ситуація, яка склалася, украй негативно позначається на всьому механізмі протидї̈ «білокоміриевій злочинності».

Ключові слова: кримінальне провадження, судово-економічна експертиза, документи ревізій і перевірок, суб'єкти фінансового контролю, джерела доказів.

Постановка проблеми. Понад півстоліття тому відомий кримінолог Е. Сатерленд в одній із публікацій виклав концепцію так званої «білокомірцевої злочинності», якою, по суті, започаткував стигматизацію протиправної діяльності осіб, які є працівниками державних органів, представниками «ділового світу», бізнесу [1]. Розуміння високого ступеня небезпеки цього явища презентують незаперечні факти. По-перше, висока латентність протиправної діяльності «еліт». Зазвичай кримінальні операції проводяться тихо, за добре спланованими, замаскованими схемами й миттєво не викликають відчутні негативні наслідки для громадян, що могло б спровокувати значний суспільний резонанс, 
як, наприклад, вибух у метро чи жорстоке вбивство. Хвилю обурення може викликати тільки інформація постфактум про значні суми втрат для держави, економіки, суспільства. По-друге, «білокомірцева злочинність» часто діє під прикриттям впливових у державі осіб, які не зацікавлені у справному функціонуванні правового механізму протидії кримінальній діяльності, а тому можуть чинити спротив будь-яким законодавчим ініціативам, покликаним унормувати проблемні питання практики кримінального провадження. По-третє, «білокомірцева злочинність» пов'язана з тіньовим обігом значних фінансових ресурсів, інших матеріальних активів. Аналіз таких даних потребуе залучення фахівців у галузі фінансово-господарської, бухгалтерської, кредитної, податкової діяльності, з питань ціноутворення, бюджетної сфери тощо. Головним інструментом для застосування спеціальних економічних знань $є$ проведення судово-економічних експертиз для підтвердження/спростування певних обставин учинення кримінального правопорушення, визначення розміру матеріальних збитків тощо. Однак це, як виявилося, сьогодні є справою надзвичайно складною, що потребує посиленої уваги й наукової спільноти, і практиків.

Питання протидії злочинності в «білих комірах» фрагментарно вивчали А. Волобуєв, О. Головченко, Т. Гулаткан, Д. Каменський, М. Корнієнко, В. Пивоваров, М. Чаплик. Засади призначення та проведення судово-економічних експертиз досліджували науковці: А. Амеліна, Л. Дікань, Н. Клименко, І. Перевозова, С. Романів та ін. Науковими розробками питань економічних експертних досліджень у рамках кримінального провадження займалися безпосередньо суб'єкти цієї діяльності, експерти-практики: С. Євдокіменко, І. Завдов'єва, К. Капустник, О. Горлачук, О. Шрамко та багато ін. Але, попри вагомий внесок указаних фахівців у розвиток тематики застосовування спеціальних економічних знань у кримінальному провадженні, як слушно зауважила Т. Крівцова, більшість праць у сучасній науковій доктрині присвячено вдосконаленню теоретичної бази та інформаційного забезпечення, натомість украй мало звертається увага на питання вдосконалення правового забезпечення порядку проведення судово-економічних експертиз [2, с. 49].

Заповнити цю прогалину стало метою статті, а саме визначити суперечності між нормами права та чинною судово-слідчою практикою залучення судових експертівекономістів для проведення експертиз у кримінальних провадженнях.
Виклад основного матеріалу.

Правове регулювання проведення судово-економічних експертиз у кримінальному провадженні

Нормативно-правове забезпечення для кожного виду судових експертиз має вирішальне значення для реалізації вимоги якісного виконання поставлених завдань. Безперечно, потрібною є праця, спрямована на вдосконалення цих правових приписів з урахуванням нових викликів, які постають перед правоохоронними органами. 3 іншого боку, часті зміни процедур і правил негативно впливають на практику судових експертиз, адже така «законодавча інфляція», часті хаотичні, а подекуди відверто непродумані зміни призводять до появи колізій і прогалин, що тягнуть за собою необхідність корегування методик експертних досліджень, зміни в переліку об'єктів, які скеровуються експерту, тощо [3, с. 499; 4, с. 90; 5, с. 166]. Інколи такі недовершені реформи можуть узагалі «паралізувати» систему кримінального судочинства. Як приклад звернемо увагу на кілька ключових позицій державного ratio, що втілені в правових приписах і внормовують залучення експертівекономістів до кримінального провадження сьогодні.

Позиція 1. Згідно зі ст. 1 Закону України «Про судову експертизу» від 25.02.1994 № 4038-XII, «судова експертиза це дослідження на основі спеціальних знань у галузі науки, техніки, мистецтва, ремесла тощо об'єктів, явищ і процесів з метою надання висновку з питань, що є або будуть предметом судового розгляду».

Позиція 2. Відповідно до ч. 1 ст. 242 Кримінального процесуального кодексу (далі КПК) України від 13.04.2012 № 4651-VI, експертиза проводиться експертною установою, експертом або експертами, яких залучають сторони кримінального провадження або слідчий суддя за клопотанням сторони захисту, у випадках і порядку, передбачених ст. 244 КПК України, якщо для з'ясування обставин, що мають значення для кримінального провадження, необхідні спеціальні знання.

Законодавець передбачив вичерпний перелік обмежень щодо питань, які можуть бути потрібні для дослідження експерту в кримінальному провадженні:

- запитання, які ставляться експертові, та його висновок щодо них не можуть виходити за межі спеціальних знань експерта (ч. 4 ст. 101);

- не допускається проведення експертизи для з'ясування питань права (ч. 1 ст. 242). 
Будь-які інші обмеження в указаних нормативно-правових документах відсутні.

Позичія 3. Законом України «Про прокуратуру» від 14.10.2014 № 1697-VII унесено зміни до КПК України, а саме з 2015 р. перестав діяти п. 4 ч. 2 ст. 40 КПК України, тобто скасовано норму, яка передбачала можливість проведення з ініціативи органу досудового розслідування позапланових перевірок і ревізій.

Позииія 4. Відповідно до останнього абзацу п. 1.1 розділу III Науково-методичних рекомендацій з питань підготовки та призначення судових експертиз та експертних досліджень, затверджених Наказом Міністерства юстиції України від 08.10.1998 № 53/5, існуе припис такого нормативного змісту: «Проведення ревізійних дій (визначення експертами-економістами будь-яких економічних показників без попереднього проведення документальних перевірок фінансово-господарської діяльності суб'єктом контролю) не належить до завдань економічної експертизи».

Позииія 5. Значна частина судовоекономічних експертиз проводяться для визначення розміру матеріальних збитків, заподіяних у зв'язку з учиненням кримінального правопорушення. Це обставина є обов'язковим елементом предмета доказування. Крім того, доповнення ч. 2 ст. 242 КПК України п. 6 пов'язано $з$ реалізацією вимог Закону України «Про внесення змін до деяких законодавчих актів України у сфері державної антикорупційної політики у зв'язку 3 виконанням Плану дій щодо лібералізації Європейським Союзом візового режиму для України» від 13.05.2014 1261-VII. Згідно з ч. 2 прикінцевих положень цього правового акта, доручено Кабінету Міністрів України у тримісячний строк з дня набрання чинності цим нормативним актом гармонізувати галузеве законодавство та привести його у відповідність до правових позицій цього Щакону. Однак «віз і нині там». Суттєвих зрушень у регламентації судово-економічних експертиз досі не зроблено.

Колапс системи, або наслідки «вибухівки сповільненої дї̈» в практиці кримінальних проваджень

Розглянемо докладніше, як вади законодавчої логіки рефлексують у хибах практики. Відомо, що предметом судово-економічної експертизи є фінансово-господарські операції, які є відображенням стану та результатів діяльності суб'єктів економічних відносин, а об'єктами є документи бухгалтерського, податкового обліку, фінансової звітності, що містять інформацію про таку діяльність [6, с. 164]. Головним джерелом даних про порушення є акти ревізій і позапланових перевірок. Саме ці документи скеровуються експертам-економістам із типовим питаннями «чи підтверджується документально...». Утім сьогодні ця практика зайшла в глухий кут.

Тривалий час слідчі діяли за алгоритмом звернення до слідчих суддів 3 метою отримання дозволів на проведення ревізій з метою подальшого проведення судової експертизи. Слідчими суддями такі клопотання задовольнялися, виносилися відповідні ухвали на проведення позапланових ревізій. У свою чергу, ці ухвали не могли бути оскаржені в апеляційній інстанції внаслідок відсутності у відповідному переліку.

У 2018 р. ця практика почала змінюватися. Ухвалою Верховного Суду Украіни (далі - ВСУ) від 06.03.2018 у справі № 243/6674/17-к у п. 51 констатовано, що слідчий суддя, надавши слідчому дозвіл на проведення перевірки, вийшов за межі своїх повноважень і прийняв рішення, яке не передбачене кримінальним процесуальним законодавством [7]. Далі Постановою ВСУ від 23.05.2018 встановлено, що апеляційні суди зобов’язані відкривати апеляційне провадження за скаргами на ухвали слідчих суддів про надання дозволу на проведення позапланових перевірок [8]. Переважна подальша практика судів: суди першої інстаниії дозволу на проведення перевірок не дають, а в разі винесення таких ухвал вони часто скасовуються апеляиійною інстаниією.

Як наслідок, провести позапланову ревізію в передбачений законом спосіб стало «місією неможливою», що суперечить цілій низці інших правових норм. Візьмемо як приклад практику розслідування кримінальних правопорушень, підслідних Національному антикорупційному бюро України (далі - НАБУ). Згідно зі ст. 11 п. 5 Закону України «Про основні засади здійснення державного-фінансового контролю в Україні» від 26.01.1991 № 2939-XII, позапланова ревізія, результат якої $€$ основним документом, що надається експерту-економісту, проводиться за дорученням НАБУ. Аналогічна норма є у відомчому законі. У пункті 2 ч. 2 ст. 19-2 Закону України «Про Національне антикорупційне бюро України» від 14.10.2014 1698-VII також визначено, що Національний банк України, Антимонопольний комітет України, Фонд державного майна України, орган державного фінансового контролю в Україні, Національне агентство $з$ питань запобігання корупції, а також інші державні органи, що здійснюють державний контроль за дотриманням фізичними та юридичними особами законодавства 
України, з метою запобігання та протидії кримінальним правопорушенням, зарахованим до підслідності НАБУ, зобов'язані (!) за зверненням НАБУ проводити в межах своєї компетенції ревізії, перевірки й інші дії щодо контролю за дотриманням законодавства України фізичними та юридичними особами. Позапланова виїзна ревізія може здійснюватися лише за наявності підстав для її проведення й на процесуальній підставі рішення суду. Відтак, незважаючи на існування иих норм, доручати проведення позапланової ревізї̈ неможливо у зв'язку з колізією в законодавстві, що дає підстави судовим органам аргументувати протилежну правову позицію.

У зв'язку з викладеним набула поширення інша, проте не менш проблемна практика проведення судово-економічних експертиз на підставі довідок спеціалістів. Відповідно до ст. 71 КПК України, спеціалістом у кримінальному провадженні є особа, яка володіє спеціальними знаннями та навичками застосування технічних або інших засобів і може надавати консультації під час досудового розслідування й судового розгляду з питань, що потребують відповідних спеціальних знань і навичок. Тож слідчі шляхом скерування листа ставили запитання спеціалістам, які, консультуючи, надавали інформацію у вигляді довідки.

Очевидно, що довідка спеціаліста не $\epsilon$ актом ревізії чи актом перевірки уповноваженого контролюючого органу. На суттєву різницю між довідкою спеціаліста та документальною перевіркою фінансово-господарської діяльності суб'єктом контролю неодноразово вказував ВСУ:

- у Постанові ВСУ від 20.03.2019 (справа № 808/3230/17) звернуто увагу, що участь посадової особи Державної фінансової інспекції як спеціаліста, у перевірках, що проводяться правоохоронними органами, за наслідками яких спеціаліст надає довідкову інформацію, та участь такої особи в проведенні ревізій, результати яких оформлюються актом, не є тотожними поняттями [9];

- у Постанові ВСУ від 27.02.2018 (справа № 826/818/16) висловлено правову позицію, що службова особа органу державного фінансового контролю, яка залучена як спеціаліст для проведення перевірки в рамках кримінального провадження, не проводить заходів фінансового контролю [10];

- у Постанові ВСУ від 27.04.2020 (справа № 335/2108/17) Акт позапланової ревізії визнано недопустимим доказом унаслідок його отримання не в порядку, передбаченому КПК України. Відповідно, висновок судовоекономічної експертизи, який грунтувався на Акті ревізії, без посилань на конкретні доку- менти, що слугували джерелом даних, також визнаний недопустимим доказом [11];

- у Постанові ВСУ від 17.09.2019 (справа № 243/2194/18) у ситуації залучення спеціаліста Управління Східного офісу Держаудитслужби в Донецькій області на підставі листа слідчого управління ГУНП в Донецькій області та складення довідки від 03.08.2017 про перевірку окремих питань фінансово-господарської діяльності, під час чого встановлено збитки на конкретну суму, також убачалися порушення. Суд першої інстанції дійшов висновку, що прокурор і слідчий не мають повноважень призначати ревізії та перевірки, а КПК не передбачено право або обов'язок спеціаліста встановлювати дотримання або порушення окремих питань фінансово-господарської діяльності шляхом проведення перевірки з питань, які, відповідно до ч. 1, п. 1 ч. 5 ст. 69 КПК України, можуть бути предметом експертного дослідження. Зазначений доказ, отриманий унаслідок такої не передбаченої КПК України перевірки чи ревізії, згідно з положенням п. 2 ч. 3 ст. 87 КПК України, є недопустимим. При дослідженні інших доказів, у тому числі висновку судово-економічної експертизи, суд, апелюючи до практики Свропейського суду з прав людини («Балицький проти України», «Тейксейра де Кастро проти Португалії», «Шабельник проти України»), застосував доктрину «плодів отруєного дерева», за якою недопустимими визнаються не лише докази, безпосередньо отримані внаслідок порушення, а також докази, яких не були б отримано, якби не було отримано перших. Отже, суд визнав недопустимим джерело доказів - висновок судової економічної експертизи від 22.09.2017 № 1332, оскільки на вирішення експерту поставлено запитання щодо підтвердження висновків, викладених у довідці про перевірку, а зазначену довідку суд визнав недопустимим джерелом доказів через отримання їі в порядку, не передбаченому КПК України [12]

Абсурдність ситуації посилює й те, що цілком правомірно судові експерти-економісти скеровують органам досудового розслідування клопотання в межах кримінальних проваджень i, посилаючись на згаданий вище Наказ Міністерства юстиції України від 08.10.1998 № 53/5, вимагають надання документів перевірок фінансово-господарської діяльності уповноваженим суб'єктом контролю, без яких виконання судово-економічних експертиз неможливе

\section{Висновки}

Сказане дає підстави для таких висновків:

1) беззаперечною $€$ необхідність існування ефективного правового порядку проведення судових економічних експертиз у кримінальних провадженнях. Такий підхід 
є не тільки важливим компонентом внутрішньої кримінально-процесуальної політики, а й чітким сигналом для міжнародної спільноти, який засвідчує прагнення України гармонізувати стандарти правоохоронної діяльності й законодавство в рамках співпраці з європейським співтовариством;

2) виходячи зі змісту загальних засад залучення судового експерта, стає очевидним, що єдиною та достатньою підставою для проведення експертизи у кримінальному провадженні є наявність потреби в спеціальних знаннях для з'ясування обставин, що мають значення для досудового розслідування й подальшого судового розгляду;

3) позбавлення можливості органів досудового розслідування ініціювати позапланові ревізії та перевірки уповноваженими суб'єктами фінансового контролю, а разом із тим заборона судовим експертам брати в них участь, як й іншим представникам органів фінансового контролю, i, що вкрай небезпечно, не надання жодного нового правового механізму, дієвої альтернативи для ефективного виконання завдань призводять до «безсилля» системи кримінального провадження щодо «білих комірців», що, своєю чергою, породжує відчуття режиму їх безкарності.

\section{Список використаних джерел:}

1. Sutherland E. H. Is «White Collar Crime» Crime? American Sociological Review. 1945. Issue 10. P. 132-139.

2. Крівцова Т.О. Удосконалення правового забезпечення судово-економічної експертизи як форми економічного контролю. Бізнес Інформ. 2015. № 2. C. 48-53.
3. Савченко I.O., Глущенко C.I. Проблемні питання при застосуванні в експертній практиці методик проведення судово-економічних експертиз. Криминалистика и судебная экспертиза. 2013. Вып. 58 (2). С. 498-502.

4. Дуфенюк O.М. Експертиза у кримінальному провадженні за законодавством України та Польщі: порівняльне дослідження. Львів : ЛьвДУВС, 2018. 272 с.

5. Дуфенюк О.М. Забезпечення судово-експертної діяльності у кримінальному провадженні: системна парадигма. Вісник Львівського торговельно-економічного університету. 2019. Вип. 8. C. $163-173$.

6. Шрамко О.М. Можливості судово-економічних експертиз при розслідуванні окремих корупційних злочинів. Актуальні проблеми правознавства. 2019. Вип. 1. С. 162-165.

7. Ухвала Верховного Суду України від 06.03.2018. Справа № 243/6674/17-к. URL: https://reyestr.court.gov.ua/Review/72670536.

8. Постанова Верховного Суду України від 23.05.2018. Справа № 237/1459/17. URL: https:// verdictum.ligazakon.net/document/74475877.

9. Постанова Верховного Суду України від 20.03.2019. Справа № 808/3230/17. URL: https:// verdictum.ligazakon.net/document/80854808.

10. Постанова Верховного Суду України від 27.02.2018. Справа № 826/818/16. URL: https://zakononline.com.ua/court-decisions / show $/ 72505887$.

11. Постанова Верховного Суду України від 27.04.2020. Справа № 335/2108/17. URL: https://zakon.cc/court/document/read/ 89034958_0b7c6ffc.

12. Постанова Верховного Суду України від 17.09.2019. Справа № 243/2194/18. URL: https://zakononline.com.ua/court-decisions/ show/84449791.

Oleksandr Tsyvinskyi, Oksana Dufeniuk. Challenging issues of forensic economic examination in criminal proceedings

The article is devoted to the discussion of a practical problem of using economic knowledge in criminal proceedings. The purpose of this study is to determine the contradictions between the current rules of law and the practice of forensic economic examinations.

It is proved that legislation is important for every type of forensic examination. Very often conclusions on financial and economic transactions should be prepared by a forensic expert on the basis of unscheduled audits and inspections. After the legislation reform, in 2015 the possibility of conducting such actions at the initiative of pre-trial investigators was eliminated. For a long time, investigators applied to the court forpermission forunscheduled audits and inspections, but this practice was stopped in 2018 by the Supreme Court of Ukraine. Its decisions expressed the legal position that judges are not authorized to make such decisions. The second path was to involve employees of financial control bodies or expert units as specialists. This practice was also stopped by the Supreme Court of Ukraine because such actions disagree with current law. Therefore, the courts apply the doctrine of "poisoned tree fruit" and recognize the conclusions of such forensic economic examinations as inadmissible sources of evidence.

Consequently, from one side, the pre-trial investigation authorities lost the opportunity to initiate and conduct unscheduled audits and inspections. They have received difficulties with involvement forensic economic experts on legal grounds. From the other side, the requirement to clarify the circumstances that need to be proved and to conduct economic examinations in criminal proceedings further is still relevant.

The authors of the article are convinced that the current situation has an extremely negative impact on the whole mechanism of combating "white-collar crimes".

Key words: criminal proceedings, forensic economic examinations, documents of audits and inspections, financial control authorities, sources of evidence. 